\title{
SYNTHESIS OF ORGANOPHOSPHORUS COMPLEXES AND STRUCTURAL CHARATERIZATION OF TWO DIMERIC TRIPHENYLPHOSPHINNE COMPLEXES OF MERCURY(II) IONS FROM DIMERIC COMPLEXES OF [4-METHYLBENZOYLMETHYLENETRI-P-TOLYLPHOSPHINE MERCURY(II) HALIDES
}

\author{
ALIREZA DADRASS*, HOJJATOLLAH RAHCHAMANI \\ Department of Chemistry, Faculty of Science, Urmia University, Urmia 57159, Iran
}

\begin{abstract}
The organophousphorus complexes of $\left[\left(\mathrm{PPh}_{3}\right)_{2} \mathrm{Hg}_{2} \mathrm{Cl}_{4}\right](\mathbf{4}),\left[\left(\mathrm{PPh}_{3}\right)_{2} \mathrm{Hg}_{2} \mathrm{Br}_{4}\right](\mathbf{5})$ and $\left[\left(\mathrm{PPh}_{3}\right)_{2} \mathrm{Hg}_{2} \mathrm{I}_{4}\right]$ (6) were resulted from nucleophilic substitution of triphenylphosphine ligand with tri-p-tolylphophine complexes (1-3). The crystal structures of two organophousphorus complexes of mercury(II) ions 4 and 6 have been determined by means of the X-ray diffraction. Both complexes were crystallized in the monoclinic space groups $P 2(1) / c$, and have very similar bond lengths, angles pattern and same substituted triphenylphosphine ligand. Single crystal X-ray analysis of title structures reveal the presence of a centrosymmeteric dimeric structure containing the ligand and mercury halides.
\end{abstract}

Keywords: Organophousphorus complexes; Phosphorus complexes; Theoretical studies of dimeric compounds; crystal structure triphenyl complexes

\section{INTROUDUCTION}

The validity of metalated phosphorus ligands in organometallic chemistry has been well documented. ${ }^{1,2}$ Phosphorus ylides are reactive compounds, which take part in many reactions of value in the synthesis of organic products..$^{3-6}$ They are synthetic targets of interest, because of their importance for a variety of industrial, biological and chemical synthetic uses. ${ }^{7-9}$ The electronic and steric effects of bulky phosphines in metal complexes such as those of $\mathrm{Hg}(\mathrm{II}), \mathrm{Au}(\mathrm{I})$ and $\operatorname{Mo}(0)^{10-13}$, have attracted attention for several years. Our interest stems primarily from the effects that the phosphines exert on the stereochemistry of the metal atoms to which they are bonded. Mercury phosphine complexes embody a wide range of structural types, with those of 1:1 complexes being especially diverse. ${ }^{6}$ We are reporting both crystal structures of $\mathbf{4}$ and $\mathbf{6}$ by the nucleophilic substitution of strong triphenylphosphine ligand with $\alpha$-keto stabilized tri-p-tolyl phosphine ligand. By a comparison of the data collected and single crystal X-ray diffraction of $\mathbf{4}$ and $\mathbf{6}$, they demonstrate nucleophilic substitution of $\mathrm{PPh}_{3}$ with [4-methybenzoylmethyllene tri-p-tolylphosphine in mercury(II) halides complexes through P-coordination as trans-like structure.

\section{EXPERIMENTAL}

\section{Instruments and reagents}

Diethyl ether $\left(\mathrm{Et}_{2} \mathrm{O}\right)$ was distilled over a mixture of sodium and benzophenone just before use. All other solvents were reagent grade and used without further purification. Mercury halides, triphenylphosphine mercury halides, tri- $p$-tolylphophine were purchased from Merck. Melting points were measured on a SMPI apparatus. Elemental analysis for $\mathrm{C}$ and $\mathrm{H}$ were performed using a PE 2400 series analyzer. Fourier transform IR spectra were recorded on a Shimadzu 435-U-04 spectrophotometer and samples were prepared as $\mathrm{KBr}$ pellets. X-ray analysis was performed on a Bruker Smart Apex diffractometer using SMART software diffractometer. The ${ }^{1} \mathrm{H},{ }^{13} \mathrm{C}$ and ${ }^{31} \mathrm{P}$-NMR spectra were recorded at 300.13, 75.46 and $121.49 \mathrm{MHz}$, respectively on BRUKER DRX300 AVANCE spectrometer in DMSO- $d$, as solvent.

General Procedure for the synthesis of compounds 1-3: The binuclear complexes were prepared by the following general procedure and their structure suggested according to published article. ${ }^{13}$ To tri-p-tolylphophine $(152 \mathrm{mg}$, $0.5 \mathrm{mmol})$ in $\mathrm{MeOH}(20 \mathrm{~mL})$ was added to $\mathrm{HgCl}_{2}(135 \mathrm{mg}, 0.5 \mathrm{mmol})$. The mixture was stirred for $24 \mathrm{~h}$ at room temperature. The solution was filtered off, and white product was washed with $\mathrm{Et}_{2} \mathrm{O}$. The corresponding bromo and iodo complexes were prepared with $\mathrm{HgBr}_{2}(180 \mathrm{mg}, 0.5 \mathrm{mmol})$ and $\mathrm{HgI}_{2}(229 \mathrm{mg}$, $0.5 \mathrm{mmol})$, respectively by the same method.

General Procedure for the synthesis of componds 4-6: A solution of triphenylphosphine $(131 \mathrm{mg}, 0.5 \mathrm{mmol})$ in methanol $(15 \mathrm{~mL})$ was added to a solution of complex $1(708 \mathrm{mg}, 0.5 \mathrm{mmol})$ in dry methanol $(5 \mathrm{~mL})$ and stirred for $24 \mathrm{~h}$. The colorless solution was concentrated to $5 \mathrm{~mL}$, and diethyl ether $(15 \mathrm{~mL})$ added to precipitate the complex 4 , which was recrystallized from chloroform/diethyl ether.

The corresponding bromo and iodo complexes 5, $\mathbf{6}$ were prepared with
$\mathrm{HgBr}_{2}(180 \mathrm{mg}, 0.5 \mathrm{mmol})$ and $\mathrm{HgI}_{2}(229 \mathrm{mg}, 0.5 \mathrm{mmol})$, respectively by the same method.

Selected data for the compound 4: White crystals; $312-314{ }^{\circ} \mathrm{C}$; Yield: 91\%. FT-IR (KBr) $\left(v_{0,} \mathrm{~cm}^{-1}\right): 3053(\mathrm{w}), 1570(\mathrm{~m}) .{ }^{1} \mathrm{H}$ NMR (DMSO- $d_{6}$, $300.13 \mathrm{MHz}) \delta_{\mathrm{H}}(\mathrm{ppm}): 7.57-8.73\left(15 \mathrm{H}, \mathrm{m}\right.$, arom). ${ }^{13} \mathrm{P}$ NMR $\left(\mathrm{CDCl}_{3}, 121.49\right.$ MHz) $\delta_{\mathrm{p}}(\mathrm{ppm}): 32.05(\mathrm{~s}){ }^{13} \mathrm{C} \mathrm{NMR}\left(\mathrm{CDCl}_{3}, 75.46 \mathrm{MHz}\right) \delta_{\mathrm{C}}(\mathrm{ppm}): 126.25$, 129.83, 133.59, 133.72 (4C). Anal. Calcd. for $\mathrm{C}_{36} \mathrm{H}_{30} \mathrm{Hg}_{2} \mathrm{Cl}_{4} \mathrm{P}_{2}$ (1068): C, 40.50; H, 2.83. Found: $\mathrm{C}, 40.79 ; \mathrm{H}, 2.70 \%$.

Selected data for the compound 5: White crystals; $300-303^{\circ} \mathrm{C}$; Yield: $85 \%$. FT-IR ( $\mathrm{KBr})\left(v_{w a}, \mathrm{~cm}^{-1}\right): 3054\left(_{w}\right), 1581(\mathrm{~m}) .{ }^{1} \mathrm{H}$ NMR (DMSO- $d_{6}$, $300.13 \mathrm{MHz}) \delta_{\mathrm{H}}(\mathrm{ppm}): 7.96-8.75\left(15 \mathrm{H}, \mathrm{m}\right.$, arom). ${ }^{13} \mathrm{P} \mathrm{NMR}\left(\mathrm{CDCl}_{3}, 121.49\right.$ MHz) $\delta_{\mathrm{p}}(\mathrm{ppm}): 32.08(\mathrm{~s}) .{ }^{13} \mathrm{C}$ NMR $\left(\mathrm{CDCl}_{3}, 75.46 \mathrm{MHz}\right) \delta_{\mathrm{C}}(\mathrm{ppm}): 127.17$, 130.33, 133.89, 134.52 (3C). Anal. Calcd. for $\mathrm{C}_{36} \mathrm{H}_{30} \mathrm{Hg}_{2} \mathrm{Br}_{4} \mathrm{P}_{2}$ (1244): C, 34.72 ; H, 2.43 . Found: C, 34.95; H, $2.32 \%$.

Selected data for the compound 6: White crystals; $247-249^{\circ} \mathrm{C}$; Yield: $85 \%$. FT-IR ( KBr) $\left(v_{\text {max }}, \mathrm{cm}^{-1}\right): 3051(\mathrm{w}), 1583(\mathrm{~m}) .{ }^{1} \mathrm{H}$ NMR (DMSO- $d_{6}$, $300.13 \mathrm{MHz}) \delta_{\mathrm{H}}(\mathrm{ppm}): 7.51-8.67\left(15 \mathrm{H}, \mathrm{m}\right.$, arom). ${ }^{13} \mathrm{P}$ NMR $\left(\mathrm{CDCl}_{3}, 121.49\right.$ MHz) $\delta_{\mathrm{p}}(\mathrm{ppm}): 32.04(\mathrm{~s}) .{ }^{13} \mathrm{C}$ NMR $\left(\mathrm{CDCl}_{3}, 75.46 \mathrm{MHz}\right) \delta_{\mathrm{C}}(\mathrm{ppm}): 126.04$ 129.61, 133.38, 133.49 (4C). Anal. Calcd. for $\mathrm{C}_{36} \mathrm{H}_{30} \mathrm{Hg}_{2} \mathrm{I}_{4} \mathrm{P}_{2}$ (1435): C 30.17, H 2.11 . Found: C 30.47 , H 2.03\%.

\section{RESULTS AND DISCUSSION}

Reactions of $\mathrm{PPh}_{3}$ ligand with complexes $\mathbf{1 - 3}$ in a 2:1 stoichiometry afforded halide-bridged structures 4-6 containing P-coordinated $\mathrm{PPh}_{3}$ ligand to metal halides (Scheme 1).

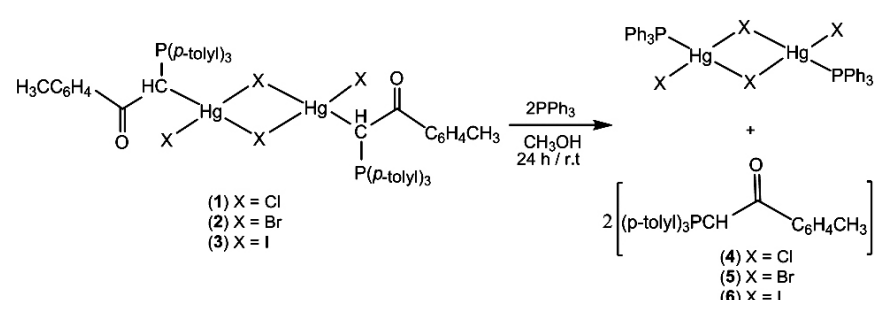

Scheme 1. Synthetic route for the compounds 4-6.

X-ray crystallography: Single crystals were carefully selected under a polarizing microscope in order to perform their structural analysis by X-ray diffraction. Single-crystals of two complexes $\mathbf{4}$ and $\mathbf{6}$ were used for data collections on a Bruker Smart Apex diffractometer using SMART software. ${ }^{14}$ A block colorless crystals of $\mathbf{4}$ and $\mathbf{6}$ having approximate dimensions of $0.46 \times 0.38 \times 0.30 \mathrm{~mm}$ and $0.62 \times 0.13 \times 0.07 \mathrm{~mm}$ were mounted on a glass fiber 
using epoxy-based glue. The data sets were collected at 293(2) K for both samples employing a scan of $0.3^{\circ}$ in $\omega$ with an exposure time of $20 \mathrm{~s} /$ frame. The cell refinement and data reduction were carried out with SAINT. ${ }^{15}$ The program SADABS was used for the absorption correction. ${ }^{15}$ The structures were solved by direct methods using SHELXS- $97^{16}$ and difference Fourier syntheses. Full-matrix least-squares refinement against|F2| were carried out using the SHELXTL-PLUS ${ }^{16}$, suit of programs. All non-hydrogen atoms were refined anisotropically.

Computational methods: The geometry of the free ligand $\mathrm{PPh}_{3}$ and their metal complexes $\left[\left(\mathrm{PPh}_{3}\right)_{2} \mathrm{Hg}_{2} \mathrm{X}_{4}\right](\mathrm{X}=\mathrm{Cl}, \mathrm{Br}$ and $\mathrm{I})$ were performed using density functional theory (DFT) calculations. The three-parameter hybrid functional B3LYP ${ }^{17}$ was used with the CEP-31G and CEP-121G $\mathrm{G}^{18}$ basis sets, implemented in the program package Gaussian $03 .{ }^{19}$ Furthermore, the natural bonding orbital (NBO) calculations ${ }^{20}$ were performed using the NBO 3.1 program as implemented in the Gaussian 03 package at the CEP- $121 \mathrm{G}$ level of theory.

Crystal structures analysis: Table 1. provides the crystallographic results and refinement in formations for complexes $\mathbf{4}$ and $\mathbf{6}$. The molecular structures of $\mathbf{4}$ and $\mathbf{6}$ are shown in (Figure 1). Table 2. lists key bond lengths and angles for both complexes. The dimeric structure adopted by complexes $\mathbf{4}$ and $\mathbf{6}$ as
P-coordinated dinuclear mercury(II) complexes of the triphenylphosphine ligand, ${ }^{21}$ are similar to the structure of the C-coordinated dinuclear mercury(II) halide complexes of $\mathrm{Ph}_{3} \mathrm{PCHCOOEt}^{22 \mathrm{a}}$ and $\mathrm{Ph}_{3} \mathrm{PCHCOPh} .{ }^{22 \mathrm{~b}}$ The difference in coordination mode between P-coordinated and C-coordinated to $\mathrm{Hg}$ (II) can be rationalized in terms of the electronic properties and steric requirements of the ligands. The $\mathrm{Hg}(\mathrm{II})$ in $\mathbf{4}$ and $\mathbf{6}$ are $\mathrm{sp}^{3}$ hybridized and have a tetrahedral coordination environments with one short $\mathrm{Hg}-\mathrm{Cl}$ bond at distance 2.3875(14), one $\mathrm{Hg}-\mathrm{p}$ bond at distance 2.4040 (12), two asymmetric bridging $\mathrm{Hg}-\mathrm{Cl}$ bonds at distances of 2.6242(14), 2.6372(14) $\AA$ for 4 and one short $\mathrm{Hg}-\mathrm{I}$ bond at distance 2.4745(13), one Hg-p bond at distance of 2.6854(13), two asymmetric bridging $\mathrm{Hg}-\mathrm{I}$ bonds at distances of 2.9583(11), 2.9583(11) $\AA$ for $\mathbf{6}$. The internuclear distances between mercury atoms were found to be 3.85844 , and $4.00411 \mathrm{~A}^{\circ}$ in structures $\mathbf{4}$ and $\mathbf{6}$ respectively. These distances are much longer than the sum of Van der Waals radius $\left(1.5 \mathrm{~A}^{\circ}\right)$ of the two mercury atoms ${ }^{23}$ indicating the absence of significant bonding interactions between the mercury atoms in the molecular structures. The adaptation of dimeric structures in $\mathrm{Hg}(\mathrm{II})$ ylide complexes may be explained by both the preference of $\mathrm{Hg}(\mathrm{II})$ for four coordination and the stability of the 18 electron configuration around $\mathrm{Hg}(\mathrm{II})$.

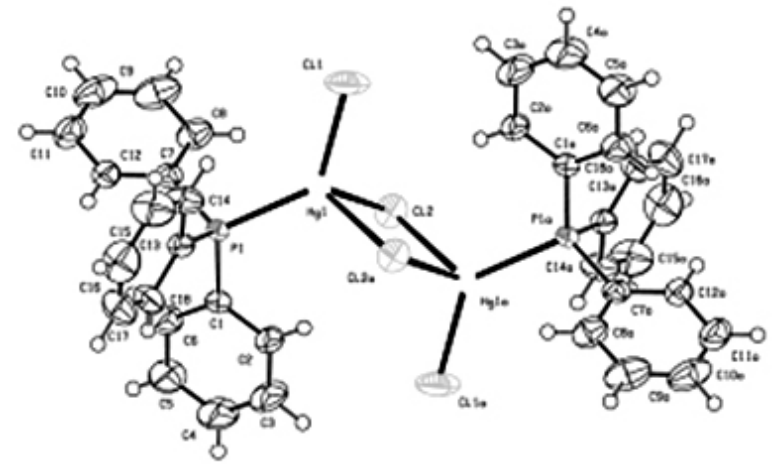

4

Figure 1. Molecular structures of the complexes 4 and 6

\section{Theoretical studies}

The geometry of the corresponding complexes $\left[\left(\mathrm{PPh}_{3}\right)_{2} \mathrm{Hg}_{2} \mathrm{X}_{4}\right](\mathrm{X}=\mathrm{Cl}$, $\mathrm{Br}$ and I) have been optimized and also the calculated structures have $\mathrm{C}_{1}$ symmetry. The final optimized geometries for complexes are shown in (Figure 2) and the optimized structure parameters are listed in (Table 2).

As can be shown in (Table 2), two different standard basis sets CEP-121G and CEP-31G were used for complexes $\mathbf{4}$ and $\mathbf{6}$ in calculations to study the possible effect of the basis set. The result of two latter calculations for these complexes agrees well with the structures determined by X-ray crystallography.

The HOMO-LUMO gap ( $\mathrm{H}-\mathrm{L}$ gap) is an important parameter to characterize the chemical reactivity and kinetic stability. ${ }^{24}$ It is well known that the energy gap retains close connection to some molecular properties. ${ }^{25} \mathrm{~A}$ soft molecule has a small HOMO-LUMO gap energy, more polarizable, high chemical reactivity and low kinetic stability. The distribution of the HOMO and LUMO orbitals for the studied compounds are presented in (Figure 3 ) and the energy gap for all compounds are collected in (Table 3). A comparison between the HOMO-LUMO gap for $\mathrm{PPh}_{3}$ and their complexes indicates that the energy gap for free ligand is higher than that in the entitled complexes. The calculated energy gap between the latter orbitals for the complex $\mathbf{6}$ containing iodine is smaller than that for other complexes and the trend is as $\mathrm{Cl}>\mathrm{Br}>\mathrm{I}$. The most important terms in this kind of interaction are contributed from the partial charge transfer between the highest occupied molecular orbital (HOMO) of one component and the lowest unoccupied molecular orbital (LUMO) of another. As shown in (Table 3), the $\left|\mathrm{HOMO}_{(\mathrm{Y})}-\mathrm{LUMO}_{(\mathrm{M})}\right|$ energy deference

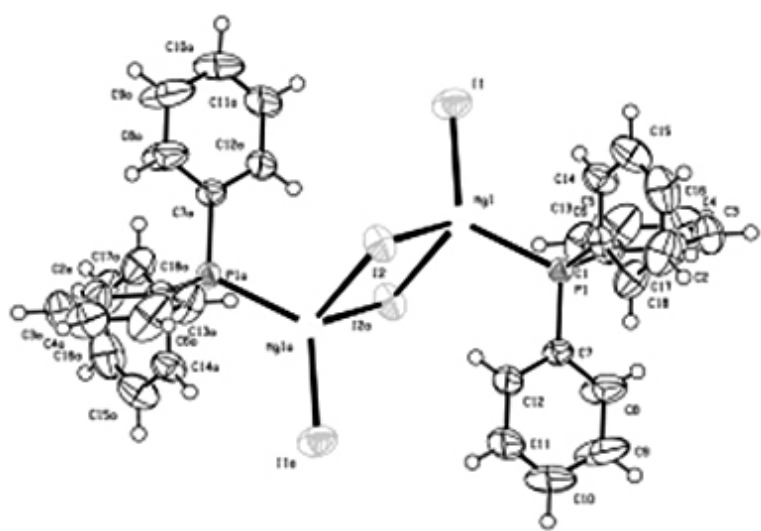

6

is considerably smaller than $\left|\mathrm{HOMO}_{(\mathrm{Y}}-\mathrm{LUMO}_{\mathrm{M}}\right|$. Furthermore, based on the theory of frontier molecular orbital, in the ligand/metal systems a significant overlap and electron density transfer can be performed between the HOMO of ligands and the LUMO of metals so that the electron transfer was occurred from HOMO of ligands $(\mathrm{Y})$ to the LUMO of metals. In continuous, we interpret the electronic structure such as partial charge of atoms and bond order via NBO analysis for the studied compounds. Table 3 gives the Wiberg bond indices $(\mathrm{WBI})^{26}$ and the results of the natural bond orbital analysis. As it can be seen, the $\mathrm{P}$ atom of phosphine group and metal center carry a positive charge and halogens carry a negative charge. Note that the total charge of the molecules is zero. Positive charge on the phosphorus atom increase for complexes compared to the $\mathrm{PPh}_{3}$ ligand ( 0.768 esu) that nicely explained by electron transfer from the ligand to the metal and halogen atoms. This is in accord with the above conclusion deduced from $\left|\mathrm{HOMO}_{(\mathrm{Y})}-\mathrm{LUMO}_{(\mathrm{M})}\right|$ energy deference. Comparing different metal complexes, the negative charge on the halogens and the positive charge on the mercury atom increase with the order $\mathrm{Cl}>\mathrm{Br}>$ $\mathrm{I}$, which is consistent with the electronegativity decrease. The Wiberg Bond Index (WBI) value, ${ }^{26}$ arises from the manipulation of the density matrix in the orthogonal natural atomic orbital basis derived through the natural population analysis. The WBI expresses the sum of squares of density matrix elements $\left(p_{j k}\right)$ and equals two times the charge density in the atomic orbital $\left(p_{i j}\right)$ minus the square of the charge density, and so is mathematically defined as bellow Equation:

$$
W B I=\sum_{k} p_{j k}^{2}=2 p_{j j}-p_{j j}^{2}
$$


Table 1. Crystal and experimental data for complexes $\mathbf{4}$ and $\mathbf{6 .}$

\begin{tabular}{|c|c|c|}
\hline Complexes & 4 & 6 \\
\hline Empirical formula & $\mathrm{C}_{36} \mathrm{H}_{30} \mathrm{Hg}_{2} \mathrm{I}_{4} \mathrm{P}_{2}$ & $\mathrm{C}_{36} \mathrm{H}_{30} \mathrm{Cl}_{4} \mathrm{Hg}_{2} \mathrm{P}_{2}$ \\
\hline Formula weight & 1433.32 & 1067.52 \\
\hline Crystal system & Monoclinic & Monoclinic \\
\hline space group & $P 2(1) / c$ & $P 2(1) / c$ \\
\hline $\mathrm{a}$ & $11.682(5)$ & $12.183(5)$ \\
\hline $\mathrm{b}$ & $12.501(5)$ & $11.380(5)$ \\
\hline $\mathrm{c}$ & $17.283(7)$ & $17.685(7)$ \\
\hline$\alpha\left(^{\circ}\right)$ & 90 & 90 \\
\hline$\beta\left({ }^{\circ}\right)$ & $126.214(5)$ & $130.589(5)$ \\
\hline$\gamma\left({ }^{\circ}\right)$ & 90 & 90 \\
\hline Volume $\left(\mathrm{A}^{3}\right)$ & 2036.6(14) & $1861.8(13)$ \\
\hline $\mathrm{Z}$, Calculated density $\left(\mathrm{Mg} / \mathrm{m}^{3}\right)$ & $2,2.337$ & $2,1.904$ \\
\hline Absorption coefficient $\left(\mathrm{mm}^{-1}\right)$ & 10.662 & 8.633 \\
\hline Theta range for data collection $\left({ }^{\circ}\right)$ & 2.16 to 28.33 & 2.20 to 28.26 \\
\hline Limiting indices & $-15 \leq \mathrm{h} \leq 15,-16 \leq \mathrm{k} \leq 16$ & $-16 \leq \mathrm{h} \leq 16,-15 \leq \mathrm{k} \leq 15$ \\
\hline & $-23 \leq 1 \leq 22$ & $23 \leq 1 \leq 23$ \\
\hline Reflections collected/unique & $24061 / 5045[\mathrm{R}(\mathrm{int})=0.0602]$ & $22197 / 4586[\mathrm{R}(\mathrm{int})=0.0625]$ \\
\hline Completeness to $\theta=28.26^{\circ}(\%)$ & 99.3 & 99.4 \\
\hline Absorption correction & Semi-empirical from equivalents & Semi-empirical from equivalents \\
\hline Max. and min. transmission & 0.2644 and 0.0374 & 0.1816 and 0.1105 \\
\hline Refinement method & Full-matrix least-squares on $F^{2}$ & Full-matrix least-squares on $F^{2}$ \\
\hline Data/restraints/parameters & $5045 / 0 / 199$ & $4586 / 0 / 199$ \\
\hline Goodness-of-fit on $F^{2}$ & 1.069 & 1.030 \\
\hline Final $R$ indices [I>2sigma(I)] & $\mathrm{R} 1=0.0433, \mathrm{wR} 2=0.1038$ & $\mathrm{R} 1=0.0345, \mathrm{wR} 2=0.0867$ \\
\hline $\mathrm{R}$ indices (all data) & $\mathrm{R} 1=0.0529, \mathrm{wR} 2=0.1089$ & $\mathrm{R} 1=0.0405, \mathrm{wR} 2=0.0900$ \\
\hline Largest diff. peak and hole $\left(\mathrm{e} . \mathrm{A}^{\mathrm{o}-3}\right)$ & 0.813 and -3.466 & 0.958 and -2.097 \\
\hline
\end{tabular}


Table 2. The selected DFT-optimized bond lengths $(\AA)$ and angles $\left(^{\circ}\right)$ for the studied complexes and compared with experimental data for compounds $\left[\left(\mathrm{PPh}_{3}\right)_{2} \mathrm{Hg}_{2} \mathrm{X}_{4}\right](\mathrm{X}=\mathrm{Cl}(\mathbf{4}), \mathrm{Br}(\mathbf{5})$ and $\mathrm{I}(\mathbf{6}))$.

\begin{tabular}{|c|c|c|c|c|c|c|c|}
\hline $\mathbf{X}$ & 4 & & & 5 & 6 & & \\
\hline & CEP-31G & CEP-121G & X-ray & & CEP-31G & CEP-121G & X-ray \\
\hline \multicolumn{8}{|l|}{ Bond lengths } \\
\hline $\operatorname{Hg}(1)-\mathrm{P}(1)$ & 2.622 & 2.634 & $2.4040(12)$ & 2.657 & 2.69733 & 2.717 & $2.6854(13)$ \\
\hline $\operatorname{Hg}(1)-\mathrm{X}(1)$ & 2.489 & 2.488 & $2.3875(14)$ & 2.610 & 2.77990 & 2.7786 & $2.4745(13)$ \\
\hline $\operatorname{Hg}(1)-X(2)$ & 2.750 & 2.724 & $2.6372(14)$ & 2.843 & 3.03614 & 3.037 & $2.9583(11)$ \\
\hline $\operatorname{Hg}(1)-X(2) i$ & 2.723 & 2.744 & $2.6242(14)$ & 2.844 & 2.97469 & 2.970 & $2.8721(13)$ \\
\hline \multicolumn{8}{|l|}{ Bond angles } \\
\hline $\mathrm{P}(1)-\mathrm{Hg}(1)-\mathrm{X}(1)$ & 122.52 & 121.57 & $129.81(5)$ & 118.86 & 116.51 & 115.40 & $119.93(4)$ \\
\hline $\mathrm{P}(1)-\mathrm{Hg}(1)-\mathrm{X}(2)$ & 101.57 & 102.01 & $110.94(5)$ & 103.66 & 103.64 & 103.61 & $113.09(4)$ \\
\hline $\mathrm{X}(1)-\mathrm{Hg}(1)-\mathrm{X}(2)$ & 115.66 & 116.51 & $102.87(6)$ & 116.56 & 103.64 & 115.72 & $112.624(16)$ \\
\hline $\mathrm{P}(1)-\mathrm{Hg}(1)-\mathrm{X}(2) \mathrm{i}$ & 107.87 & 107.75 & $114.48(4)$ & 106.69 & 105.95 & 106.08 & $104.37(4)$ \\
\hline $\mathrm{X}(1)-\mathrm{Hg}(1)-\mathrm{X}(2) \mathrm{i}$ & 115.51 & 115.67 & $103.80(6)$ & 116.31 & 118.32 & 119.27 & $109.713(19)$ \\
\hline $\mathrm{X}(2)-\mathrm{Hg}(1)-\mathrm{X}(2) \mathrm{i}$ & 87.53 & 87.541 & $85.67(4)$ & 90.569 & 93.94 & 93.720 & $93.260(11)$ \\
\hline
\end{tabular}

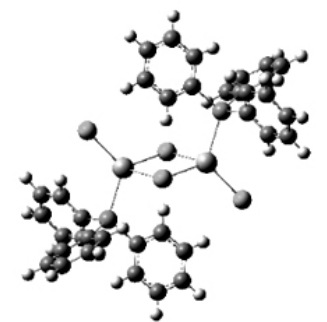

(a)

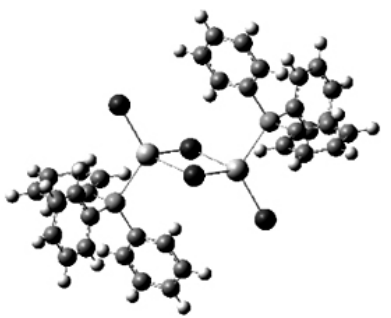

(b)

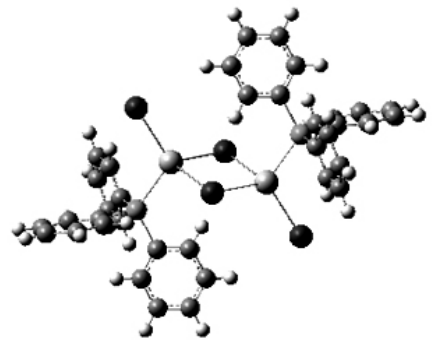

(c)

Figure 2. Optimized structure for the complex $\left(\mathrm{PPh}_{3}\right)_{2} \mathrm{Hg}_{2} \mathrm{X}_{4}$ investigated here at the B3LYP/CEP-121G level of theory.

The WBI closely relates to the bond character, that is, larger WBI means stronger covalent character. For all metal complex, the most value of the WBI is related to $\mathrm{Hg}-\mathrm{X}(1)$ bond (terminal halogen), which means that the $\mathrm{Hg}-\mathrm{X}(1)$ bond have the stronger covalent character than the other bond around mercury(II) (Table 3).

Table 3. Energies of the relevant frontier orbitals and gap energies $(\mathrm{H}-\mathrm{L})(\mathrm{eV})$ of the investigated compounds at B3LYP/ CEP-121G level, Wiberg bond indices results of the NBO analysis, dipole moment (De) of the $\mathrm{PPh}_{3}$, and $\left[\left(\mathrm{PPh}_{3}\right)_{2} \mathrm{Hg}_{2} \mathrm{X}_{4}\right](\mathrm{X}=\mathrm{Cl}(\mathbf{4}), \mathrm{Br}(\mathbf{5})$ and I (6)).

\begin{tabular}{|c|c|c|c|c|}
\hline Species & $\mathbf{P P h}_{3}$ & 4 & 5 & 6 \\
\hline HOMO (eV) & -0.223 & -0.246 & -0.240 & -0.230 \\
\hline LUMO (eV) & -0.026 & -0.082 & -0.084 & -0.085 \\
\hline $\mathrm{H}-\mathrm{L}(\mathrm{eV})$ & 5.34 & 4.27 & 4.22 & 3.94 \\
\hline \multicolumn{5}{|c|}{ Wiberg bond } \\
\hline $\mathrm{Hg}(1)-\mathrm{P}(1)$ & - & 0.450 & 0.433 & 0.412 \\
\hline $\operatorname{Hg}(1)-X(1)$ & - & 0.628 & 0.689 & 0.805 \\
\hline $\operatorname{Hg}(1)-\mathrm{X}(2)$ & - & 0.305 & 0.367 & 0.433 \\
\hline $\operatorname{Hg}(1)-X(2) i$ & - & 0.319 & 0.364 & 0.495 \\
\hline \multicolumn{5}{|c|}{ Dipole moment (De) } \\
\hline $\mathrm{X}$ & & $\mathrm{Y}$ & & Z \\
\hline 0.00 & & 0.00 & & 0.00 \\
\hline
\end{tabular}




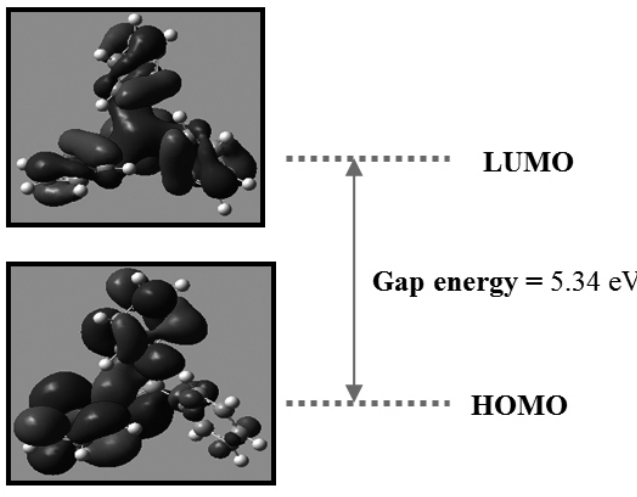

(a)
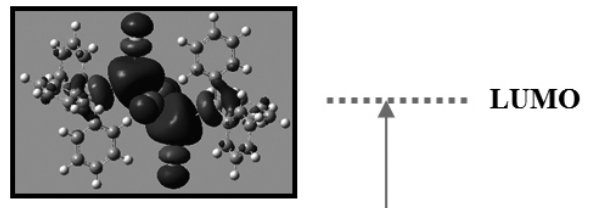

Gap energy $=4.47 \mathrm{eV}$

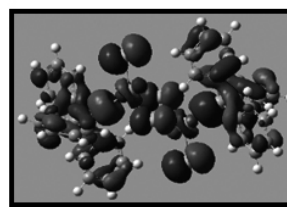

(b)

Figure 3. The frontier molecular orbital pictures of the studied sample compounds a) $\left.\mathrm{PPh}_{3} \mathbf{b}\right)\left(\mathrm{PPh}_{3}\right)_{2} \mathrm{Hg}_{2} \mathrm{Cl}_{4}$

\section{CONCLUSONS}

The present study describes the synthesis and characterization of tri-phenylphosphorus complexes of mercury(II) halides from nucleophilic substitution of dimeric complexes of 4-methybenzoylmethyllene tri- $p$ tolylphosphine mercury(II) halides. On the basis of the physicochemical and spectroscopic data we propose that all complexes are P-coordinated to the mercury(II) ions. In addition theoretical studies on the gas phase structures of 4, 5 and $\mathbf{6}$ confirms the trans-like dimeric structures for these compounds. The structures of both complexes $\mathbf{4}$ and $\mathbf{6}$ were determined by single crystal X-ray analysis.

\section{SUPPLEMENTARY MATERIAL}

CCDC 940104 and 940105 contain the supplementary crystallographic data for $\mathbf{4}$ and $\mathbf{6}$. These data can be obtained free of charge via http://www. ccdc.cam.ac.uk/conts/retrieving.html, or from the Cambridge crystallographic Data Centre, 12 Union Road, Cambridge CB2 1EZ, UK; fax: (+44) 1223-336033; or e-mail: deposit@ccdc.cam.ac.uk.

\section{ACKNOWLEDGMENTS}

The authors are grateful to Urmia University for financial support and to Dr. A. Choudhury (Missouri University of Science and Technology, USA) for his assistance with X-ray crystallography.

\section{REFERENCES}

1. P. Laavanya, U. Venkatasubramanian, K. Panchanatheswaran, J.A.K. Bauer, Chem. Commun. 1660 (2001)

2. E.C. Spencer, M.B. Mariyatra, J.A.K. Howard, A.M.K. Kenwright, J. Panchanatheswaran, Organomet. Chem. 692, 1081 (2007).

3. D.E.C. Cobridge, Phosphorus: An Outline of Chemistry, Biochemistry and Uses, 5th ed.; Elsevier: Amsterdam, 31 (1995).

4. S.J. Sabounchei, A.R. Dadrass, M. Jafarzadeh, S. Salehzadeh, H.R. Khavasi, J. Organomet. Chem. 692, 2500 (2007).

5. S.J. Sabounchei, S. Samiee, S. Salehzadeh, M. Bayat, Z.B. Nojini, D. Morales-Morales, Inorganic Chimica Acta. 363, 6 (2010).

6. A.R. Dadrass, A. Ramazani, A. Poursattar Marjani, H. Rahchamani, H Nasri Koureh, A. Souldozi, S. Samiee, K. Ślepokura, T. Lis, Chinese J. Struct. Chem. 34, 373 (2015).

7. R. Engle, Synthesis of Carbon-Phosphorus Bonds, CRC Press, Boca Raton, FL, (1988).

8. J.I.G., Cadogan, Organophosphorus Reagent in Organic Synthesis, Academic, New York, (1979).

9. B.E. Maryanoff, A.B. Reitz, Chem. Rev. 89, 863 (1989).

10. G. Ferguson, P.J. Roberts, E.C. Alyea, M.A. Khan, Inorg. Chem. 17, 2965 (1978).

11. E.C. Alyea, G. Ferguson, J.F. Gallagher, J. Malito, Acta. Crystallogr. Sect C. 49, 1473 (1993).

12. E.C. Alyea, S.Q. Song, Can. J. Chem. 74, 2304 (1996).
13. S.J. Sabounchei, A.R. Dadrass, H. Nemattalab, Asian J. Chem. 20, 4329 (2008).

14. Bruker, SMART. Bruker AXS Inc., Madison, Wisconsin, USA, (2002).

15. Bruker SAINT \& SADABS. Bruker AXS Inc., Madison, Wisconsin, USA, (2008).

16. G.M. Sheldrick, Acta. Crystallographica. A64, 112, (2008).

17. a) A.D. Becke, J. Chem. Phys. 98, 5648 (1993). b) C. Lee, W. Yang, R.G. Parr, Phys. Rev. B. 37, 785 (1988).

18. a) W.J. Stevens, H. Basch, M. Krauss. J. Chem. Phys. 81, 6026 (1984). b) W.J. Stevens, M. Krauss, H. Basch, P.G. Jasien, Can. J. Chem. 70, 612 (1992)

19. M.J. Frisch et al., GAUSSIAN 03, Revision B.03, GAUSSIAN, Inc., Pittsburgh, PA, (2003).

20. E.D. Glendening, A.E. Reed, J.E. Carpenter, F. Weinhold, NBO Version 3.1 TCI, University of Wisconsin, Madison, (1998).

21. B. Kalyanasundari, K. Panchanatheswaran, V. Parthasarathi, W.T. Robinson, Bull. Chem. Soc. Jpn. 72, 33 (1999)

22. (a) E.C. Spencer, M.B. Mariyatra, J.A.K. Howard, A.M. Kenwright, K. Panchanatheswaran, J. Organomet. Chem. 692, 1081 (2007). b) M. Kalyanasundari, K. Panchanathes Waran, W.T. Robinson, H. Wen, J. Organomet. Chem. 491, 103 (1995).

23. J.E. Huheey, Inorganic Chemistry-Principles of Structure and Reactivity, 2ed., Harper Int. Ed., New York, 233 (1978).

24. L.R. Radovic, B. Bockrath, J. Am. Chem. Soc. 127, 5917 (2005).

25. P. Thanikaivelan, V. Subraminanian, J.R. Rao, B.U. Nair, Chem. Phys. Lett. 323, 59 (2000).

26. K.B. Wiberg, Tetrahedron 24, 1083 (1968). 